Available online at https://jurnal.stmikroyal.ac.id/index.php/jurdimas

\title{
UPAYA MENDORONG PEMBELAJARAN EFEKTIF MASA PANDEMI MELALUI PELATIHAN INOVASI BELAJAR BERBASIS DIGITAL
}

\author{
Zailani Surya Marpaung $^{1 *}$, Slamet Widodo ${ }^{1}$, Nurmah Semil $^{1}$, Mardianto ${ }^{1}$ \\ ${ }^{1}$ Administrasi Publik, Universitas Sriwijaya \\ Email: *zailanisuryamarpaung@ @isip.unsri.ac.id
}

\begin{abstract}
Pandemic Covid-19 has had a direct impact on the world of education. The limitation of the crowd in community activities in public places causes the world of education to maximize the use of information and communication technology as a medium for distance learning or online. This encourages educators/ teachers to formulate alternatives for distance learning media by adapting them according to the conditions of available facilities and infrastructure, and mastering the use of a number of digital platforms that can be used as alternative learning media. This digital-based learning innovation training activity aims to introduce and assist the use of several digital learning media in one of the schools, namely SMK Lingua Prima Indralaya. Assessment of the success of the training held was carried out through a pretest and post-test. Assistance is carried out so that teachers understand and gain insight in formulating innovative learning methods in the implementation of the distance or online teaching and learning process. In this training, introduction and assistance were carried out related to the use of audio podcasts, maximizing the function of social media and also designing materials with attractive and innovative PowerPoint templates.
\end{abstract}

Keywords: digital based learning; effective learning; pandemic period

\begin{abstract}
Abstrak: Pandemi Covid-19 telah berdampak secara langsung terhadap dunia pendidikan. Dibatasinya kerumunan dalam aktivitas masyarakat ditempat umum menyebabkan dunia pendidikan harus memaksimalkan penggunaan teknologi informasi dan komunikasi sebagai media pembelajaran jarak jauh atau daring. Hal ini mendorong tenaga pendidik / guru harus merumuskan alternatif-alternatif media pembelajaran jarak jauh dengan cara mengadaptasinya sesuai dengan kondisi sarana dan prasarana yang tersedia, serta menguasai penggunaan sejumlah platform digital yang dapat digunakan sebagai media pembelajaran alternatif. Kegiatan pelatihan inovasi belajar berbasis digital ini bertujuan untuk melakukan pengenalan dan pendampingan penggunaan beberapa media pembelajaran digital di salah satu sekolah, yakni SMK Lingua Prima Indralaya. Penilaian terhadap keberhasilan pelatihan yang diselenggarakan ini dilakukan melalui pretest dan post-test. Pendampingan dilakukan agar para guru memahami dan menambah wawasan dalam merumuskan metode pembelajaran yang inovatif dalam pelaksanaan proses belajar mengajar jarak jauh atau daring. Pada pelatihan ini dilakukan pengenalan dan pendampingan terkait penggunaan podcast audio, memaksimalkan fungsi media sosial dan juga merancang materi dengan template powerpoint yang menarik dan inovatif.
\end{abstract}

Kata Kunci: masa pandemi; pembelajaran berbasis digital; pembelajaran efektif 
Jurdimas (Jurnal Pengabdian Kepada Masyarakat) Royal

Vol. 4 No. 2, Mei 2021, hlm. 165 - 172

Available online at https://jurnal.stmikroyal.ac.id/index.php/jurdimas

\section{PENDAHULUAN}

Pandemi Coronavirus Disesase (Covid-19) merupakan bencana yang sampai saat ini tidak kunjung berakhir. Hal ini bisa kita lihat dari berita-berita di media tentang perkembangan kasus Covid-19 baik tingkat orang yang terinfeksi maupun tingkat kematian korban infeksi virus Covid-19. Wabah Corona Virus Disease (Covid-19) semakin hari menunjukkan peningkatan kasus yang signifikan, tercatat hingga Jumat, 25 September 2020 kasus terkonfirmasi positif sebanyak 266.845 orang, sembuh sebanyak 196.196 orang, dan meninggal dunia sebanyak 10.218 orang (Evanalia, 2020). Dalam rangka mencegah penularan dan menekan angka korban terinfeksi, pemerintah menerapkan protokol kesehatan diantaranya menggunakan masker, menghindari kerumunan, mencuci tangan dengan sabun, menggunakan disinfektan hingga menerapkan Pembatasan Sosial Berskala Besar (PSBB), mengingat kemampuan penyebaran virus sangat cepat, bahkan dalam rentang waktu 5 bulan saja virus ini telah menginveksi 216 negara di dunia (Herliandry, Nurhasanah, Suban, \& Heru, 2020). Hal tersebut tentu berdampak signifikan terhadap semua sektor, tidak tekecuali dalam dunia pendidikan.

Pada tanggal 24 Maret 2020 Kementerian Pendidikan dan Kebudayaan mengeluarkan aturan yang mengatur Pelaksanaan Kebijakan Pendidikan dalam Masa Darurat Penyebaran Corona Virus Disease (Covid-19). Aturan tersebut meliputi pembatalan Ujian Nasional (UN), ketentuan pelaksanaan ujian sekolah, ketentuan kenaikan kelas, penerimaan peserta didik baru, penggunaan Bantuan Operasional Sekolah (BOS) atau
Bantuan Operasional Pendidikan (BOP), serta proses belajar dari rumah atau model pembelajaran daring (Menteri Pendidikan dan Kebudayaan, 2020).

Apabila dianalisa dari sejumlah aturan ini, maka proses belajar dari rumah atau model pembelajaran daring merupakan aturan yang patut menjadi fokus lembaga-lembaga penyelenggara pendidikan, mengingat penyelenggaraan pendidikan jarak jauh atau daring (dalam jaringan) membutuhkan sejumlah persiapan yang harus disiapkan oleh lembaga penyelenggara pendidikan. Ketersediaan sarana dan prasarana, serta kesiapan guru dalam menyiapkan sejumlah media pembelajaran alternatif atau inovasi belajar jarak jauh menjadi kebutuhan mendesak yang ditimbulkan pasca dikeluarkan aturan tersebut. Hal ini tentu menjadi sesuatu yang bertolak belakang dengan apa yang ada selama ini, karena kecenderungannya fungsi media pembelajaran hanya menjadi bagian dari inovasi dan kreasi pembelajaran untuk keluar dari metode klasikal yakni ceramah dan tanya jawab yang masih bersifat "Teacher Centre" (Miftah, 2014).

Kebijakan pembelajaran jarak jauh yang demikian tidak hanya terjadi di Indonesia, China sebagai negara yang telah lebih dulu mengambil kebijakan pendidikan darurat karena merupakan negara pertama yang terkena pandemi juga mengalami sejumlah tantangan yang hampir sama, terutama persoalan infrastruktur (Zhang, Wang, Yang, \& Wang, 2020)

Pada masa pandemi, model pembelajaran jarak jauh atau daring (dalam jaringan) dengan memaksimalkan fungsi teknologi informasi dan komunikasi merupakan solusi yang paling mungkin untuk dilakukan guna tetap berlangsungnya proses belajar 
Available online at https://jurnal.stmikroyal.ac.id/index.php/jurdimas

mengajar bagi peserta didik, meskipun sebenarnya tanpa adanya pandemi, perkembangan teknologi informasi telah merubah konsep pendidikan secara berangsur-angsur yang berkembang sesuai dengan perkembangan zaman (Isa, 2015), karena kecenderungan teknologi informasi dan komunikasi pada era globalisasi saat ini telah memberikan pengaruh yang signifikan terhadap hampir keseluruhan sendi-sendi kehidupan sehari-hari termasuk dunia pendidikan (Lestari, 2015), yang pemanfaatannya memiliki tantangan tersendiri untuk menyesuaikan dengan fungsinya dalam praktik dunia pendidikan (Yuhdi \& Amalia, 2018).

Sejak dikeluarkan aturan tentang proses belajar dari rumah atau belajar jarak jauh, banyak media pembelajaran yang bermunculan, sejumlah media video conference, podcast video dan audio, laman-laman e-learning berbasis web dan aplikasi, hingga optimalisasi media sosial sebagai media pembelajaran.

Penggunaan media pembelajaran yang terkoneksi dengan sejumlah perangkat teknologi informasi bukan sesuatu hal yang tidak mungkin untuk dilakukan, mengingat penggunaan internet dalam kehidupan sehari-hari dewasa telah menjadi kebiasaan baru bagi masyarakat kita. Misalnya pada tahun 2016, Survei Asosiasi Penyelenggara Jaringan Internet Indonesia (APJII) menunjukkan bahwa pengguna internet di Indonesia sebanyak $51,8 \%$, yakni 132,7 juta dari 256,2 juta orang penduduk Indonesia (Wicaksono \& Rachmadyanti, 2016).

Sejumlah lembaga-lembaga penyelenggara pendidikan di level Sekolah Dasar (SD), Sekolah Lanjutan Tingkat Pertama (SLTP), dan Sekolah Lanjutan Tingkat Atas (SLTA) mencoba merumuskan alternatif-alternatif media pembelajaran jarak jauh dengan cara mengadaptasinya sesuai dengan kondisi sarana dan prasarana sekolah, guru, serta kondisi peserta didik dan sarana/ prasarana pendukungnya. Meskipun berlangsung belum efektif, lembagalembaga penyelenggara pendidikan mencoba memaksimalkan alternatif yang dipilih sembari terus mengembangkannya sebagai upaya mendorong pembelajaran efektif dengan sejumlah keterbatasan-keterbatasan yang ada. Hal ini tentu berbeda dengan level perguruan tinggi di Indonesia, karena sebagian besar perguruan tinggi telah mengembangkan sistem perkuliahan jarak jauh/daring dengan platform digital tertentu yang disiapkan dengan memanfaatkan sumber daya perguruan tinggi yang relatif besar.

SMK Lingua Prima merupakan salah satu sekolah di Ogan Ilir yang secara signifikan merasakan dampak dari kebijakan kuliah jarak jauh tersebut, apalagi berstatus sebagai sekolah kejuruan, tentu praktik di laboratorium sekolah menjadi rutinitas pembelajaran yang saat ini terbatas untuk dilakukan.

Pelaksanaan pembelajaran jarak jauh di SMK Lingua Prima juga menghadapi sejumlah tantangan, keterbatasan sarana dan prasarana dibeberapa daerah menyebabkan peserta didik tidak dapat mengikuti proses pembelajaran dengan efektif. Misalnya saja, peserta didik yang bertempat tinggal di beberapa daerah dengan kualitas jaringan internet yang kurang stabil akan kesulitan mengakses mediamedia pembelajaran tertentu, dikarenakan beberapa media pembelajaran seperti media pembelajaran video conference membutuhkan kualitas jaringan internet yang stabil untuk dapat mengaksesnya, dan tentu hal itu tidak hanya terjadi pada peserta didik di SMK Lingua Prima saja, 
Available online at https://jurnal.stmikroyal.ac.id/index.php/jurdimas

karena senyatanya memang media pembelajaran jarak jauh tertentu membutuhkan kuota internet yang cukup besar, apalagi harus digunakan secara terus menerus setiap hari akan menyebabkan banyak peserta didik yang mengeluhkan biaya kuota internet yang harus dikeluarkan, sementara kondisi ekonomi masyarakat pada masa Covid19 tercatat menurun (Purwanto, Pramono, Asbari, Santoso, Wijayanti, Choi, \& Putri, 2020).

Selain itu tantangan lainnya yang dihadapi oleh SMK Lingua Prima adalah metode pembelajaran yang identik dengan pemberian tugas secara terus menerus akan menyebabkan kejenuhan tersendiri bagi peserta didik, ditambah lagi penggunaan media-media pembelajaran yang tidak variatif oleh para guru akan berpengaruh terhadap minat dan semangat belajar peserta didik, karena pada dasarnya pada dunia pendidikan selain kualitas sarana dan prasarana, peningkatan sumber daya manusia juga dipengaruhi oleh kualitas tenaga pendidik dalam pemanfaatan media-media pembelajaran yang variatif (Utomo \& Ubaidillah, 2018).

Hal ini terlihat seragam terjadi pada proses pembelajaran jarak jauh/daring yang terjadi hampir di semua lembaga pendidikan di Indonesia saat ini, yang menyebabkan Pendidikan berlangsung monoton. Praktik pembelajaran jarak jauh secara monoton dengan pemberian tugas kepada peserta didik yang terjadi di SMK Lingua Prima dan sebagian besar lembaga penyelenggara pendidikan di Indonesia bukan satu-satunya persoalan, karena hal tersebut bertentangan dengan prinsip pendidikan yang pada dasarnya tidak hanya berfungsi sebagai transfer of knowledge saja, tetapi juga transfer of value (Makhromi, 2017). Hal ini tentu memiliki kendala tersendiri dalam tataran operasionalnya, terbatasnya interaksi antara guru dan peserta didik menyebabkan transfer of value diantara keduanya berlangsung tidak maksimal, sehingga dibutuhkan media alternatif untuk memfasilitasi interaksi keduanya ditengah diterapkannya aturan pembelajajaran jarak jauh/daring.

Berdasarkan wawancara prakegiatan yang dilakukan dengan salah seorang unsur pimpinan di SMK Lingua Prima, ada harapan bahwa situasi pembelajaran jarak jauh dapat mendorong para guru untuk lebih adaptif dengan perkembangan teknologi informasi dan komunikasi, terutama memperkaya pengetahuan dan pemahaman terkait sejumlah media pembelajaran digital yang terus berkembang. Karena penguasaan para guru terhadap hal tersebut tentu akan berdampak signifikan terhadap minat dan semangat belajar peserta didik meskipun dengan interaksi yang terbatas.

\section{METODE}

Metode pelaksanaan yang digunakan dalam kegiatan pengabdian kepada masyarakat ini berbentuk penyuluhan dengan memberikan beberapa referensi materi tentang inovasi belajar berbasis digital yang kemudian dilanjutkan dengan pendampingan para peserta untuk melakukan praktik dan uji coba beberapa media yang telah dijelaskan pada sesi penyuluhan. Ketika pendampingan berlangsung, peserta juga difasilitasi sesi tanya-jawab dan diskusi terkait penggunaan beberapa media dalam inovasi belajar berbasis digital.

Kegiatan ini dilaksanakan di SMK Lingua Prima Indralaya. Pelaksanaan kegiatan lapangan sendiri dilakukan pada 
Available online at https://jurnal.stmikroyal.ac.id/index.php/jurdimas

bulan Oktober - November 2020. Selama periode kegiatan ini akan dilakukan dalam 3 kali tatap muka. Periode kegiatan ini juga termasuk didalamnya pelaksanaan kegiatan seperti prapemberian materi, saat pemberian materi, pasca pemberian materi dan monitoring. Hal ini ditujukan dalam rangka memetakan pemahaman peserta kegiatan secara keseluruhan. Peserta dalam kegiatan ini terdiri 27 orang yang merupakan guru/ tenaga pendidik yang ada di lingkungan SMK Lingua Prima Indralaya.

\section{PEMBAHASAN}

Pada kegiatan pengabdian kepada masyarakat ini dilakukan pelatihan inovasi belajar berbasis digital, tim pengabdian melakukan pengenalan dan pendampingan beberapa metode kreatif yang bisa digunakan dalam proses belajar jarak jauh atau daring. Adapun beberapa metode tersebut antara lain penggunaan Podcast Audio, Optimalisasi Media Sosial sebagai media pembelajaran, serta memak-simalkan desain Powerpoint dan metode penggunaannya dalam proses pembelajaran jarak jauh atau daring.

\section{Aplikasi Podcast Audio}

Podcast audio merupakan sebuah aplikasi yang berbentuk rekaman. Dimana rekaman tersebut bisa didengarkan oleh khayalak ramai. Podcast audio bisa dinikmati kapanpun dan dimanapun orang bisa membutuhkannya. Selain bisa diakses streaming, podcast audio juga bisa diunduh dan disimpan. Podcast tersedia dalam beberapa kategori topik, baik itu bisnis, pendidikan, kesehatan, musik, teknologi, hiburan, olahraga dan lain sebagainya. Kita bisa memilih sendiri tema dan topik yang akan didengarkan sesuai dengan minatnya. Podcast bisa didengar dan diunduh melalui aplikasi Spotify.

Data dilapangan menunjukkan hanya $13 \%$ saja peserta yang mengetahui adanya Podcast pada aplikasi Spotify tersebut. Namun setelah diberikan pendampingan, $83 \%$ peserta mengetahui dan memahami bagaimana aplikasi itu bisa digunakan sebagai sarana pembelajaran jarak jauh atau daring.

Dari data diatas bisa disimpulkan bahwa, materi yang diberikan kepada peserta pengabdian yang notabenenya adalah para guru di SMK Lingua Prima sangat berpengaruh terhadap pengetahuan mereka akan salah satu aplikasi yang bisa digunakan dalam proses belajar mengajar. Diharapkan dengan beberapa metode baru yang diterapkan, peserta didik tidak bosan dalam proses sistem pembelajaran daring.

\section{Optimalisasi Media Sosial}

Media sosial sangat bermanfaat untuk melakukan komunikasi, edukasi, rekreasi, promosi, diseminasi berinteraksi, dll. Tapi di sisi lain media sosial sering digunakan oleh orang-orang yang tidak bertanggung jawab untuk menyebar konten-konten negatif seperti hoax, ujaran kebencian, fitnah, provokasi, menghasut dan lain-lain. Hal ini sangat berbahaya yang berpotensi memicu kebencian, kemarahan, yang menyebabkan disintegrasi bangsa (Kemenkominfo, 2018).

Banyak media sosial yang bisa dioptimalkan pemanfaatannya dalam proses kegiatan pembelajaran sistem daring. Media-media sosial tersebut antara lain whatsapp, facebook, instagram, youtube, twitter, dan lain-lain. Pemanfaatan media sosial dapat 
Available online at https://jurnal.stmikroyal.ac.id/index.php/jurdimas

dimanfaatkan oleh guru dalam memberikan informasi baik itu terkait dengan materi bahan ajar, pemberian tugas, pelaporan tugas, dan lain sebagainya, bahkan para guru dapat memaksimalkannya sebagai media transfer of value dengan mengawasi aktivitas media sosial para peserta didiknya. Melalui pemanfaatan dan pengoptimalan media sosial, bisa diyakini akan dapat lebih mengarahkan peserta didik cerdas dalam pemanfaatan perkembangan teknologi informasi dan komunikasi.

\section{Desain Powerpoint dan Metode Publikasinya}

Powerpoint berfungsi sebagai alat untuk menampilkan poin-poin yang akan disampaikan dalam sebuah materi/bahan ajar. Melalui powerpoint, materi yang akan dipresentasikan menjadi lebih ringkas. Powerpoint yang dikemas dalam template desain yang lebih menarik akan menjadikan penerima materi merasakan tidak jenuh, tidak mudah bosan, tidak mengantuk dan merasa tampilan materi yang monoton dapat diminimalisir. Penambahan warna, bentuk, efek suara, video dan animasi lainnya membuat powerpoint yang dibuat lebih menarik untuk disimak. Tidak semua orang mengetahui bahwa powerpoint yang baik itu seperti apa. Sebagian orang beranggapan bahwa fungsi powerpoint hanya membantu mengingatkan poinpoin yang akan dijelaskan saja.

Powerpoint yang dikemas dengan atraktif, lebih singkat, padat, jelas dan tidak membosankanakan dapat membuat peserta lebih fokus kepada materi yang disampaikan ketika menjelaskan poin yang disampaikan dibanding peserta membaca poin-poin yang disajikan dalam bentuk tulisan yang panjang.
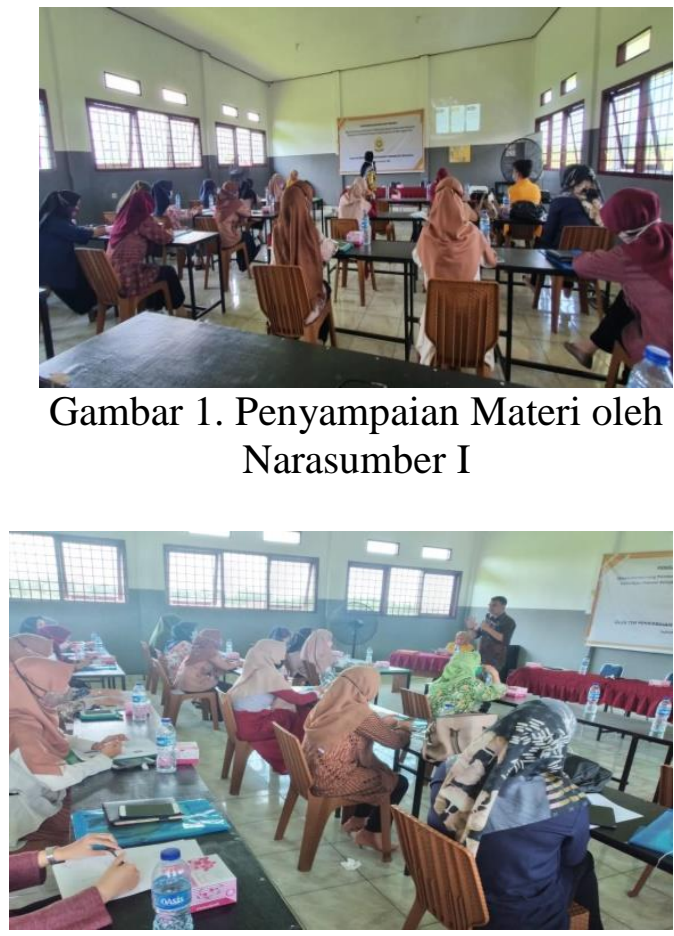

Gambar 2. Penyampaian Materi oleh Narasumber II

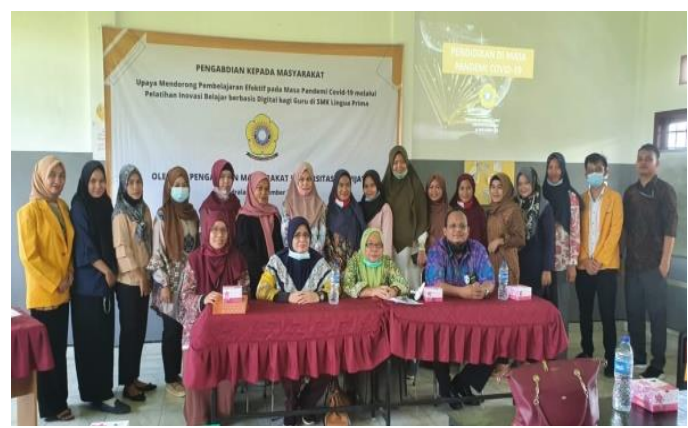

Gambar 3. Dokumentasi Kegiatan

\section{SIMPULAN}

Setelah penyelenggaraan kegiatan pengabdian kepada masyarakat yang diselenggarakan dalam bentuk pelatihan inovasi belajar berbasis digital ini guruguru di SMK Lingua Prima menambah wawasannya terkait penggunaan teknologi informasi dan komunikasi, bertambahnya pengetahuan dan pemahaman para guru terkait beberapa media yang dijelaskan melalui kegiatan ini 
Available online at https://jurnal.stmikroyal.ac.id/index.php/jurdimas

dapat disimpulkan melalui lembar evaluasi kegiatan yang menunjukkan terjadi perubahan signifikan pengetahuan dan pemahaman para guru terkait penggunaan media-media tersebut.

Hal ini juga diiringi dengan antusiasnya para guru menguji coba secara langsung penggunaan mediamedia yang disampaikan, sehingga terjadi interaksi langsung dalam waktu yang panjang antara para guru dan tim pengabdian masyarakat, karena dimulai dari pembuatan akun sampai dengan penggunaan media dan cara memaksimalkan media tersebut untuk pembelajaran.

\section{DAFTAR PUSTAKA}

Evanalia, S. (2020). Update Corona 25 September: 266.845 Positif, $196.196 \quad$ Sembuh, 10.218 Meninggal. Retrieved September 26, 2020, from https://kompas.tv/article/111139/ update-corona-25-september-266845-positif-196-196-sembuh-10218-meninggal

Herliandry, L. D., Nurhasanah, Suban, M. E., \& Heru, K. (2020). Pandemic learning during the Covid-19. Jurnal Teknologi Pendidikan, 22(1), 65-70. Retrieved from http://journal.unj.ac.id/unj/index. $\mathrm{php} / \mathrm{jtp}$

Isa, Y. (2015). Pengembangan Model Blended Learning Mata KuliahPerencanaan Teknologi Pembelajaran Teknologi Informasi dan Komunikasi. Jurnal Teknologi Pendidikan, 17(2), 73-83.

Kemenkominfo. (2018). Memaksimalkan Penggunaan Media Sosial dalam
Lembaga Pemerintah. Jakarta: Dirjen Infokom Publik Kemenkominfo.

Lestari, S. (2015). Faktor-Faktor Yang Mempengaruhi Pemanfaatan Tik Oleh Guru. Jurnal Kwangsan, $3(2)$, 121. https://doi.org/10.31800/jurnalkw angsan.v3i2.29

Makhromi. (2017). PENDIDIK YANG BERJIWA MENDIDIK: Upaya Mewujudkan Pendidikan Humanis Perspektif Tradidi Pendidikan Islam. Occupational Medicine, 53(4), 130.

Menteri Pendidikan dan Kebudayaan. (2020). Surat Edaran Menteri Pendidikan dan Kebudayaan Nomor 4 Tahun 2020 Tentang Pelaksanaan Kebijakan Pendidikan dalam Masa Darurat Penyebaran Corona Virus Disease (Covid-19).

Miftah, M. (2014). Pemanfaatan Media Pembelajaran Untuk Peningkatan Kualitas Belajar Siswa. Jurnal Kwangsan, 2(1), 1. https://doi.org/10.31800/jurnalkw angsan.v2i1.11

Purwanto, A., Pramono, R., Asbari, M., Santoso, P. B., Wijayanti, L. M., Choi, C. H., \& Putri, R. S. (2020). Studi Eksploratif Dampak Pandemi COVID-19 Terhadap Proses Pembelajaran Online di Sekolah Dasar. EduPsyCouns: Journal of Education, Psychology and Counseling, 2(1), 1-12. Retrieved from https://ummaspul.ejournal.id/Edupsycouns/article/vi ew/397

Utomo, S. W., \& Ubaidillah, M. (2018). Pemanfaatan Aplikasi Whatsapp Pada Pembelajaran Berbasis Masalah Untuk Mata Kuliah 
Jurdimas (Jurnal Pengabdian Kepada Masyarakat) Royal

Vol. 4 No. 2, Mei 2021, hlm. 165 - 172

Available online at https://jurnal.stmikroyal.ac.id/index.php/jurdimas

Akuntansi Internasional Di

Universitas Pgri Madiun.

Kwangsan: Jurnal Teknologi

Pendidikan, 6(2), 199-211. https://doi.org/10.31800/jtp.kw.v 6n2.p199--211

Wicaksono, V. D., \& Rachmadyanti, P. (2016). Pembelajaran Blended Learning melalui Google Classroom di Sekolah Dasar. Seminar Nasional Pendidikan PGSD UMS \& HDPGSDI Wilayah Timur, 513-521. Retrieved from http://hdl.handle.net/11617/9144

Yuhdi, A., \& Amalia, N. (2018). Desain Media Pembelajaran Berbasis
Daring Memanfaatkan

PortalSchoology pada Pembelajaran Apresiasi Sastra. Basastra, 7(1), 14. https://doi.org/10.24114/bss.v7i1. 9320

Zhang, W., Wang, Y., Yang, L., \& Wang, C. (2020). Suspending Classes Without Stopping Learning: China's Education Emergency Management Policy in the COVID-19 Outbreak. Journal of Risk and Financial Management, 13(3), 55. https://doi.org/10.3390/jrfm13030 055 